\title{
Drug patents: the high price of watchdog litigation
}

$\mathrm{N}$ all patents are created equal. Actually, if you were to ask someone in the generic drug business, you'd likely get an earful about patents owned by brandname pharmaceutical companies that are weak, questionable or shouldn't have been granted in the first place.

"In the pharmaceutical industry, generic drug companies act as a mediator or sheriff on these patents, because they can't bring products to market unless they challenge these patents," says Jim Keon, president of the Canadian Generic Pharmaceutical Association. "If generic companies just sat back passively, they would never come to market with their products."

Why should anyone outside the pharmaceutical trade care about these frequent court battles? Well, according to Keon, the high cost of litigation is becoming a bigger burden for the generic industry as provinces slash the prices of generic drugs, which could delay the products' entry into the market.

"If you cut the prices too low, generics can no longer afford litigation. They will sit back and be more passive, and the provinces will be paying for brandname products for much longer," says Keon. "You don't want to kill the goose that's laying the golden eggs. We want to provide low prices, but not ridiculously low prices."

Typically, generic drug companies don't go after patents on drugs that are actually novel - genuine, withoutquestion, brand-spanking-new molecular entities. They will wait for the 20-year lifespans of those patents to expire before seeking market approval for generic versions. The same cannot be said, however, about the suite of patents for slight variations of the original drug that could, in effect, extend the brand-name company's monopoly for many years.

To gain market approval from Health Canada for a generic version of an off-patent molecule with stillpatented cousins, a generic company

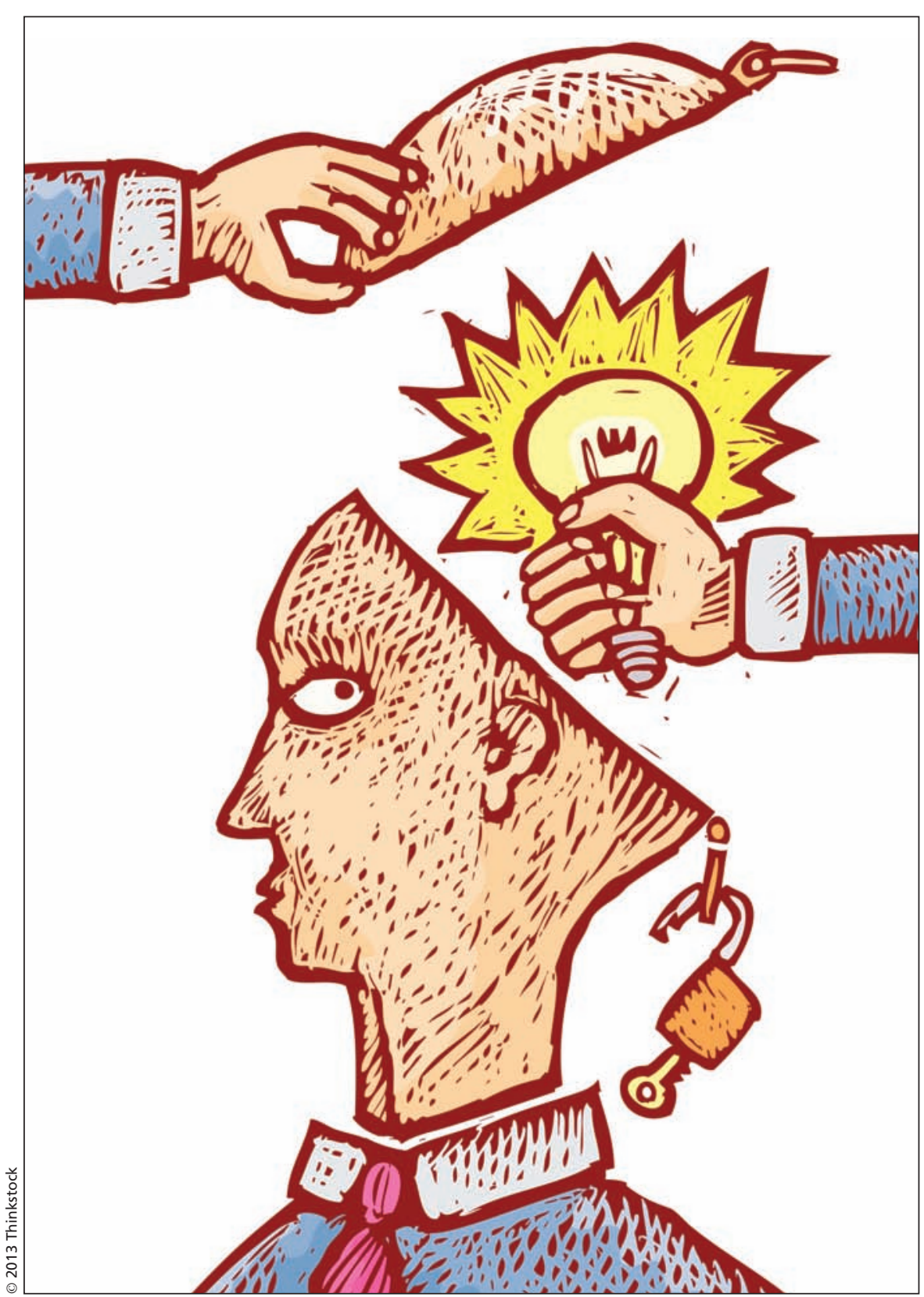

The generic drug industry depends on the ideas and innovations of brand-name pharmaceutical companies and litigation over intellectual property rights is part of doing business.

has two choices. It can prove the derivative patents are invalid. Or it can prove they are not infringing upon those patents. But even if the generic company succeeds and is found not to be infringing at this stage, it can still be sued for infringement by a brand-name company after it begins selling its generic product.

Keon claims this "double jeopardy" isn't permitted in the United States or Europe, and shouldn't be allowed in Canada either. "It's put a real chill on the generic drug industry," he says. 
Then again, perhaps complaints about too many costly court battles have little merit, considering litigation may be at the very heart of the generic industry's business model. These companies do, after all, rely quite heavily on other people's ideas and innovations to turn a profit, says Patrick Kierans, the global head of pharmaceuticals and life sciences for the international law firm Norton Rose.

"The generic drug companies, let's be clear, they have a parasitical business model. I'm not criticizing it; I'm just saying it's parasitical," says Kierans. "They don't develop; they simply take. They take the benefits of the risks, but they never make drugs that don't work, and they wait until someone else develops a market."

That said, the generic industry does indeed play a crucial role, acknowledges Kierans. Brand-name companies realize they will face competition once their patents expire, so they can't simply churn out a few cash cows and call it a day. "It's an incentive to take a lot of the money they are making and plow it back into the next generation of innovation," he says. "It does keep them honest."
So perhaps the generic industry's role as watchdog of shaky patents is an important one. Does that also mean provinces should stop lowering the prices of generic drugs so the companies that make them can keep paying their lawyers? Not at all, suggests Michael Law, an assistant professor at the Centre for Health Services and Policy Research, University of British Columbia, in Vancouver.

Historically, the prices of generic drugs in Canada have been grossly inflated, says Law. They still, despite multiple cuts in various provinces in recent years, remain higher than in countries such as New Zealand and the United States, where prices are driven lower than Canadian-level caps through head-to-head competition for consumers' money.

Instead of focusing on pricing, governments should create other incentives for generic drug companies to challenge patents, suggests Law. In the US, for example, a generic company that comes out on top in litigation with a brand-name firm is granted a six-month exclusivity period. That could prove extremely lucrative in Canada, especially if the first-to-market generics find their way onto provincial formularies. Another alternative would be to make competitors pay royalties to the generic companies that fight and win the court battles that allow the generic products to come to market.

"If you put into place some sort of incentive, and offer a reward for successfully challenging a patent, there is little reason, as far as I can see, that we should still be paying a premium for drugs that have been off patent for 20 or 30 years," says Law. "Instead of tossing millions of dollars at the system and hoping you get litigation, you actually directly incentivize firms to engage in the litigation you want." — Roger Collier, CMAJ

CMAJ 2013. DOI:10.1503/cmaj.109-4474

Editor's note: This is the third of a three-part series on patents at cmaj.ca: "Drug patents: innovation v. accessibility" and "Drug patents: the evergreening problem." 